\title{
SUBSURFACE RELATIONSHIPS OF ALBIAN-CENOMANIAN SHALLOW MARINE TO NONMARINE TOPSETS OF THE NANUSHUK FORMATION, NORTHWESTERN NPRA, NORTHERN ALASKA
}

\author{
Paul L. Decker ${ }^{1}$ and David L. LePain ${ }^{2}$
}

\begin{abstract}
This brief text and accompanying poster (sheet 1-1) provide regional stratigraphic and structural context for the Wainwright 1 and 1A wells drilled in 2007 by the U.S. Geological Survey (USGS) to investigate coalbed methane potential in the northwestern National Petroleum Reserve-Alaska (NPRA). The Wainwright 1 well was cored continuously from 75 to 1,605 ft (22.9-489.2 m) total depth, and a suite of high-resolution, slim-hole well logs has been compiled from both holes, providing a unique dataset for interpreting the sedimentology, stratigraphic architecture, and reservoir quality of Brookian topset strata of the middle and upper Nanushuk Formation.

The Wainwright 1/1A core and log data document the upward transition from predominantly marine to fully nonmarine depositional settings accompanying east-northeastward progradation of topset strata during Albian to Cenomanian time. Tentative correlations with wells up to tens of kilometers away are possible with the benefit of seismic data. Intervals of fluvial sandstone up to $30 \mathrm{~m}$ thick (recognized in core and well logs) that appear to correlate across these long distances are interpreted as mobile channel-belt deposits; their continuity suggests they are associated with sequence boundaries (regressive surfaces of erosion) that are otherwise difficult to interpret in nonmarine settings. Many coal-bearing intervals also appear to correlate across these long distances, but it is considered unlikely that individual coal seams or sand bodies are continuous among the widely separated wells. The plausible widespread correlation of coaly intervals (likely late transgressive to early highstand systems tracts) and mobile channel belts (likely falling stage to lowstand systems tracts) suggests that expansive areas of the Nanushuk coastal plain were subject to changes in relative sea level, probably due to low relief.
\end{abstract}

\section{DISCUSSION}

This brief paper is part of a three-chapter study that also includes detailed core description and facies analysis (LePain and Decker 2016 [this volume]) and reservoir quality study (Helmold, 2016 [this volume]). This chapter's objective is to place the continuously cored Wainwright $1 / 1 \mathrm{~A}$ well into its regional context using seismic and well log correlations and to note details in core and logs from the well that reflect that greater framework.

The location map (fig. 1-1 of sheet 1-1) identifies the Wainwright $1 / 1 \mathrm{~A}$ location relative to other key exploration wells (Tunalik 1, Peard 1, and Kugrua 1) drilled in northwestern NPRA, as well as the regional two-dimensional (2-D) public seismic grid acquired by the USGS. Seismic transect $A-A^{\prime}$ is spliced together from several different lines to roughly approximate the path of well log correlation section B-B'. Transect A-A' is longer than section B-B', (197 versus $120 \mathrm{~km}$ ), providing context beyond the points of well control on both the west and east ends. The overall west-southwest to east-northeast orientation of both sections is dictated by the location of wells in the area, but is also a reasonable approximation of the general depositional dip and progradation direction in this part of the North Slope during Albian to Cenomanian time (Molenaar, 1985; Huffman and others, 1985).
Several Nanushuk Formation conventional gas reservoirs were discovered in the late 1940s through the mid-1960s in anticlinal traps in the northern foothills compressional province (Schindler, 1988). None of those discoveries lie on the seismic transect or well log section; the Nanushuk gas accumulation discovered by the Meade 1 well is shown to the southeast in figure 1-1 (sheet 1-1).

Figure 1-2 (sheet 1-1) shows two versions of the interpreted seismic transect; the upper version is displayed using a sea level datum, and the lower version is flattened on a shallow horizon in the Nanushuk Formation topsets in this area. Several major bends in the transect significantly exaggerate the structural expression of the Meade Arch. The arch is clearly expressed in the thickness variations of the Ellesmerian and Beaufortian units, but at the Nanushuk level in the area of these wells, structure has a nearly homoclinal southerly dip.

A key aspect of the seismic interpretation is the markedly time-transgressive nature of the toplap surface between the foreset seismic facies (Torok Formation) and the topset seismic facies (predominantly Nanushuk Formation); the purple horizon clearly steps across seismic reflections. The topset seismic facies can be further subdivided into a lower, relatively transparent interval characterized by minor internal acoustic contrast, and an upper, relatively reflective interval with greater

\footnotetext{
${ }^{1}$ Alaska Division of Oil and Gas, 550 West 7th Avenue, Suite 800, Anchorage, AK 99501-3560; paul.decker@alaska.gov

${ }^{2}$ Alaska Division of Geological \& Geophysical Surveys, 3354 College Road, Fairbanks, AK 99709-3707; david.lepain@alaska.gov
} 
impedance contrast. Integrated with log and lithologic data from the wells, these intervals are interpreted to correspond to the dominantly marine lower Nanushuk and dominantly nonmarine, coal-bearing upper Nanushuk strata. The orange seismic horizon represents the gradational contact between the marine- and nonmarinedominated topsets. Correlations with the wells suggest this transition is also time transgressive, although to a lesser degree than the toplap surface at the base of the topsets, with the most pronounced up-section step located between the Peard 1 and Kugrua 1 wells.

The well correlation section of figure 1-3 (sheet 1-1) is flattened on a shallow datum picked in seismic data and tied to well control using integrated sonic log time-depth relationships. The center track of the composite log display is color coded to depict log-derived interpretations of lithology. Given the tens of kilometers between wells and the nonmarine to shallow marine setting, all correlations are tentative and inferred to represent approximately time-equivalent horizons, not necessarily continuous lithosomes. Even so, it appears reasonable to correlate two intervals containing the thickest channel-fill sandstones in Wainwright 1/1A (1,060-1,158 ft [323.1-353 m] measured depth [MD] and 619-667 ft [188.7-203.3 m] MD) to well-developed though slightly thinner intervals in similar stratigraphic position in the other wells. Continuity of sandstone-dominated, channelized fluvial intervals between the wells at these distances suggests they may represent broad channel belts, within which generally east-flowing stream channels migrated laterally over time, depositing sheet-like sands throughout a broad swath of the coastal plain. In addition, it is reasonable to correlate the coaly intervals penetrated at approximate depths of $100 \mathrm{ft}(30.5 \mathrm{~m}), 240 \mathrm{ft}(73.2 \mathrm{~m})$, and $305 \mathrm{ft}(93 \mathrm{~m}) \mathrm{MD}$ in Wainwright $1 / 1 \mathrm{~A}$ across long distances between wells, in the case of the lower two coals, spanning a distance of approximately $100 \mathrm{~km}$.

The widespread distribution of apparently correlative fluvial sandstones up to $30 \mathrm{~m}$ (100 ft) thick interpreted as mobile channel-belt deposits suggests they are associated with falling stage to lowstand systems tract sequence boundaries rather than local accommodation afforded by autocyclic processes. Similarly, coaly intervals present in the upper part of the Wainwright 1/1A wells appear to correlate among the widely separated wells and probably represent late transgressive to early highstand systems tracts. The lateral continuity of these systems tracts at distances approaching $100 \mathrm{~km}$ implies that expansive areas of the Nanushuk coastal plain responded approximately simultaneously to changes in relative sea level, consistent with low topographic relief.

The section penetrated by the Wainwright 1 and $1 \mathrm{~A}$ holes falls within the middle to upper portion of the Albian-Cenomanian Nanushuk Formation topsets. Below about $1,320 \mathrm{ft}(402.3 \mathrm{~m}) \mathrm{MD}$, the section appears dominated by marine facies (LePain and Decker, 2016 [this volume]), with minimal coal, and widespread occurrences of a relatively diverse suite of trace fossils (relatively common Thalassinoides as well as occasional Skolithos, Diplocraterion, Asterosoma, Rhizocorallium, Paleophycos, Teichichnus, Planolites, Phycosiphon, and Anchonichnus or Helminthopsis). Above 1,320 ft (402.3 m) MD, nonmarine characteristics predominate, including more abundant and thicker coals and zones of paleosol development (LePain and Decker, 2016 [this volume]), but there are still a number of relatively thin intervals bearing a slightly less diverse trace fossil suite (sporadic occurrences of Thalassinoides, Skolithos, Diplocraterion, Rossellia, Rhizocorallium, and Paleophycos). Above about $265 \mathrm{ft}(80.8 \mathrm{~m}) \mathrm{MD}$, there are no indications of marine influence, with strata interpreted to represent deposition entirely in alluvial to upper delta plain environments (LePain and Decker, 2016 [this volume]). Thus, the Wainwright $1 / 1 \mathrm{~A}$ well is interpreted to illustrate the general upward transition toward more proximal facies, consistent with the overall progradational nature of the Nanushuk Formation.

\section{SUMMARY}

Two themes emerge from placing the continuously cored Wainwright $1 / 1 \mathrm{~A}$ in its regional context. First, coalbearing horizons and fluvial channel-belt deposits exhibit a high degree of lateral continuity, at least in the proximalto-distal direction, in the middle and upper Nanushuk Formation of the western North Slope. This is consistent with depositional responses linked to changes in relative sea level across expansive systems tracts. Second, the core and context provide new insights into the frequency and extent of marine and brackish influence on dominantly nonmarine facies of the lower delta plain.

\section{ACKNOWLEDGMENTS}

The authors thank several colleagues whose assistance made this study possible. David Houseknecht and Arthur Clark of the USGS facilitated access to the core during its transit through Anchorage. Dede Schwarz, Dan Przywojski, and Mike McCracken of ConocoPhillips Alaska approved and arranged core layout at the Anchorage Bayview core facility. We thank Paul McCarthy and Marwan Wartes for technical reviews of the manuscript.

\section{REFERENCES CITED}

Helmold, K.P., 2016 [this volume], Sedimentary petrology and reservoir quality of Lower Cretaceous Nanushuk sandstones, USGS Wainwright \#1 test well, western North Slope, Alaska, in LePain, D.L., ed., Stratigraphic and reservoir quality studies of continuous core from the Wainwright \#1 coalbed methane test well, Wainwright, Alaska: Alaska Division of Geological \& Geophysical Surveys Report of Investigation 2016-3, 56 p. doi:doi:10.14509/29657

Huffman, A.C., Jr., Ahlbrandt, T.S., Pasternack, I., Stricker, G.D., and Fox, J.E., 1985, Depositional and 
sedimentologic factors affecting the reservoir potential of the Cretaceous Nanushuk Group, central North Slope, Alaska, in Huffman, A.C., Jr., ed., Geology of the Nanushuk Group and related rocks, North Slope, Alaska: U.S. Geological Survey Bulletin 1614, p. 61-74. LePain, D.L., and Decker, P.L., 2016 [this volume], Lithofacies analysis of the Wainwright \#1 continuous core, western Arctic Slope, Alaska-Transition from lower to upper delta plain environments in the Nanushuk Formation, in LePain, D.L., ed., Stratigraphic and reservoir quality studies of continuous core from the Wainwright \#1 coalbed methane test well, Wainwright, Alaska: Alaska Division of Geological \& Geophysical Surveys Report of Investigation 2016-3, 56 p. doi:10.14509/29656
Molenaar, C.M., 1985, Subsurface correlations and depositional history of the Nanushuk Group and related strata, North Slope, Alaska, in Huffman, A.C., Jr., ed., Geology of the Nanushuk Group and related rocks, North Slope, Alaska: U.S. Geological Survey Bulletin 1614, p. 37-60.

Schindler, J.F., 1988, History of exploration in the National Petroleum Reserve in Alaska, with emphasis on the period from 1975 to 1982, in Gryc, George, ed., Geology and exploration of the National Petroleum Reserve in Alaska, 1974 to 1982: U.S. Geological Survey Professional Paper 1399, p. 13-72. 